\title{
The efficiency wage effect of employer provided occupational pensions
}

\author{
Mario Bossler
}

\section{Correspondence:}

mario.bossler@iab.de

Institute for Employment Research (IAB), Regensburger Str. 104, 90478

Nuremberg, Germany

\begin{abstract}
Using new linked employer-employee data from Germany, this article provides the first evidence on the effect of employer provided occupational pensions on work engagement. Famous efficiency wage theories predict that pensions enhance effort if a risk of forfeiture of pension claims is present. Exploiting the German non-forfeiture clause for employer-provided pensions, the results are consistent with the theoretical prediction and show that pensions in combination with the risk of forfeiture exert a positive effect on work engagement. Since occupational pension claims are selectively distributed across establishments, I control for establishment heterogeneity, but point estimates remain of the same size. Conditional quantile regression estimates indicate that especially the lower end of the engagement distribution is affected, which suggests that pensions combined with the risk of forfeiture are effective to reduce incentives for shirking.
\end{abstract}

JEL classification: J14; J26; J32

Keywords: Occupational pensions; Non-forfeiture clause; Efficiency wages; Delayed compensation; Work engagement

\section{Introduction}

Many Germans rely solely on the public pay-as-you-go pension scheme in which pensions are financed by contemporary contributions to the social security system. Demographic change, which has led to a shrinking work force (Fuchs and Söhnlein 2013) and an increasing percentage of the older population, places increasing demands on such pay-as-you-go pension schemes. Most of the suggested policy measures to reform the pension system try to increase the share of private financial savings. Since occupational pensions are an instrument for private pension savings, they have received increasing public and political interest. In a recent comparison concerning the flexibility of pension systems, Mercers (2013) ranked Germany in the mid-field of 20 countries. Countries in the top group of the ranking, such as Denmark, the Netherlands, Switzerland, and the UK, all have particularly emphasized occupational pension schemes characterized by high participation rates. In Germany, the share of employees with occupational pension claims has been rising in the last decade, and in 2011, about $60 \%$ of the employees had claims for an occupational pension (Figure 1).

These facts lead to the major puzzle underlying this article: Why do employers provide occupational pensions at all? Theoretically, providing an occupational pension comes at

(c) 2015 Bossler; licensee Springer. This is an Open Access article distributed under the terms of the Creative Commons Attribution License (http://creativecommons.org/licenses/by/4.0), which permits unrestricted use, distribution, and reproduction in any medium, provided the original work is properly credited. 


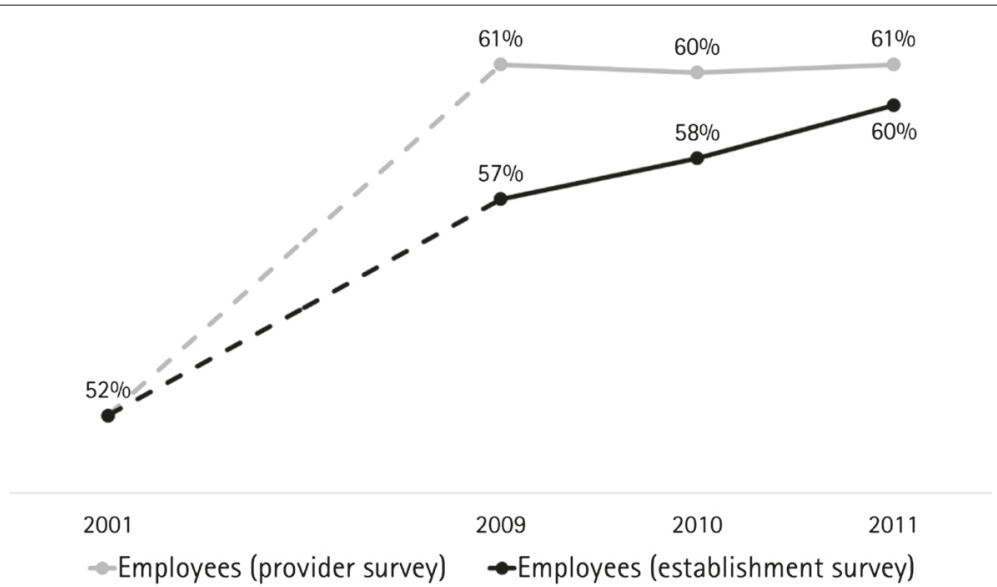

Figure 1 Occupational pension claims in Germany. Note: Population-weighted share of employees (liable to social security contributions) with pension claims. Source: Numbers retrieved from a published report of TNS Infratest Sozialforschung (2012).

a cost to the employer. The employer commits himself to pay monthly contributions and additionally, he also has to deal with the administrative costs of managing the contributions to the pension plan. To cover these costs, a rational employer expects something in return (Gustman et al. 1994; Schnabel and Wagner 2001).

Previous literature mostly analyzes whether occupational pensions are an effective tool to reduce turnover rates. While some studies cannot prove a mobility reducing effect (Andrietti 2001; Taylor 2000), most of the literature finds a negative relationship between pensions and turnover rates (Even and Macpherson 1996; Gustman and Steinmeier 1993; Henley et al. 1994; Hernaes et al. 2011; McCormick and Hughes 1984; Mealli and Pudney 1996). For Germany, Rabe (2007) suggests that the reduced turnover rates result from restricted portability of pensions, i.e., the risk of forfeiture of pension claims.

I exploit the non-forfeiture clause for employer provided pensions in Germany (BetrAVG 2009), which regulates the retention of pension claims in the case of job loss. Employees with more than five years of contributions retain their pension claims. However, employees receiving contributions for less than five years face the risk of forfeiture. In case of a credible threat of losing the pension benefits, standard efficiency wage theories suggest that wage premiums, such as pensions, can serve as an instrument to reduce incentives for shirking, i.e., they can increase average work effort. For this mechanism to operate, it requires that employers are able to lay-off workers if shirking is detected. Although Germany has strict Employment Protection Legislation by international standards, recent evidence has proven that the German labor market is in fact very un-protective, and therefore shirking theories may apply. Bauer et al. (2007) present precise evidence that the German employment protection legislation does not affect employment decisions. Moreover, studies by Bellmann et al. $(2011 ; 2013)$ show that, such as in the United States, German firms use hiring and firing to adjust employment.

In the theoretical considerations, I review standard efficiency wage theories, referring to the agency model by Shapiro and Stiglitz (1984), as well as Lazear's model of delayed compensations. The theories predict that occupational pensions reduce incentives for shirking if a risk of forfeiture is present. In line with theory, I construct an empirical model in which work effort is the dependent variable in a regression on pensions and an 
interaction capturing the risk of forfeiture. In this specification, theory predicts a positive impact of the interaction term but is uncertain about the direct effect of pensions on work engagement.

The suggested relationship between pensions and effort is prevalent in standard nonclassical wage setting theories (Akerlof 1982; Lazear 1979; Shapiro and Stiglitz 1984), but to the best of my knowledge, this is the first application testing this clear theoretical relation. In the empirical analysis, I use the Utrecht Work Engagement Scale to measure employee engagement as a proxy for effort. New German Linked Employer-Employee data allow me to control for establishment heterogeneity using employer specific observable variables or an employer specific fixed effect. The employer specific heterogeneity controls for selectivity in the provision of pensions across workplaces. Several robustness checks, which control for individual personality as well as the perceived work environment, demonstrate that omitted variables, both in the individual and the workplace dimension, are unlikely to affect the estimates. Finally, I use conditional quantile regressions to evaluate the effect of pensions on the entire conditional engagement distribution, which provides a direct test on whether the shirking hypothesis applies-that is, whether it increases effort in the lower tail of the distribution or at all points of the distribution.

The paper proceeds as follows. In Section 2, I summarize the institutional background of employer-provided pensions in Germany including the non-forfeiture clause and the average quantitative value of contributions. Section 3 summarizes the theoretical predictions from efficiency wages (Shapiro and Stiglitz 1984) and the theory of delayed compensations (Lazear 1979). Descriptive regressions in Section 5 show to what extent pension claims are selectively distributed across employers, which emphasizes the importance of incorporating this dimension in the regression analysis. In Section 6, I present the core results of this article. I provide several robustness checks to the baseline regressions in Section 7. Section 8 presents quantile regressions on the entire engagement distribution, and Section 9 concludes.

\section{Institutional background}

The 3-pillar categorization of The World Bank (1994) classifies pensions as obligatory public pensions, obligatory privately managed pensions, and voluntary privately managed pensions. In Germany, occupational pensions can be assigned to the third pillar of voluntary privately managed savings. Unlike other European countries, Germany does not demand obligatory privately managed savings.

\subsection{The non-forfeiture clause}

The major policy regulation which I exploit in this article is the non-forfeiture clause (BetrAVG 2009). It regulates whether employees retain their pension claims in the case of job termination. The current regulation requires at least five years of contributions. If an employment relationship is terminated after five years of employer provided contributions, pension claims are vested. However, if employment is terminated within the first five years of contributions, pension claims forfeit.

This contemporary regulation came into force on 1 January 2009 and replaced the old ten year non-forfeiture clause. The regulation has been reformed a few times in the past and originates from a case in law in the early 1970s when the German Federal Labour 
Court ("Bundesarbeitsgericht") decided that employees have the right to retain their pension claims after 20 years of contributions (Bundesarbeitsgericht 1972).

I exploit the contemporary five-years threshold because it ensures a credible risk of forfeiture within the first five years. ${ }^{1}$ After five years, the non-forfeiture clause expires and employees retain their pension claims. As I will show in section 3, the five-years threshold may substantially change the employees' incentives for shirking.

\subsection{Contributions to occupational pension plans}

TNS Infratest Sozialforschung (2012) provides a comprehensive longitudinal overview on occupational pensions in Germany, presenting results from surveys in which employers and a large variety of pension plan providers are interviewed on participation rates and financing issues. Representative for Germany as of 2011 , about $80 \%$ of the firms reported to offer occupational pension plans including own contribution. ${ }^{2}$ However, the survey question in the Linked Personnel Panel, which I analyze here, explicitly asks for pension claims from employer provided pension plans. Hence, I assume that a significant contribution is made by the employer.

TNS Infratest Sozialforschung (2012) also reports numbers on the average monthly contributions. In a survey of pension plan providers, the average contribution is $€ 103$ at the "Pensionskassen," which provide rather traditional saving plans, and $€ 101$ at pension funds. These descriptive figures show that independent of the kind of pension plan, a monthly contribution of about $€ 100$ is observed. This contribution can be interpreted as a future pay-off on top the monthly wage. ${ }^{3}$ Descriptive regressions on wage satisfaction presented in Additional file 1: Table S1 support the interpretation of occupational pensions as a wage premium. Regression estimates show that even after controlling for wages, bonus payments, and general job satisfaction, occupational pensions have a large and significant correlation with wage satisfaction. What is more, this perceived wage premium is of similar size for employees facing the risk of forfeiture and those whose pension claims are vested. Both groups attribute to pensions a similar impact on wage satisfaction. Because of this significant correlation with wage satisfaction, I interpret pension claims as a wage premium.

\section{Efficiency wage theories}

The standard efficiency wage theory by Shapiro and Stiglitz (1984) provides a simple theoretical framework and a clear theoretical prediction concerning occupational pensions and work effort. However, I argue that the predictions are not different from Lazear's model of delayed compensations (Lazear 1979). Even though the core of these theories provides explanations for non-classical wage setting, or even more generally, Shapiro and Stiglitz (1984) try to explain involuntary unemployment, the theories also provide implicit predictions for the relation between pensions and work effort, suggesting a positive relation if a risk of forfeiture is present.

\subsection{The Shapiro-Stiglitz model}

In their seminal paper "Equilibrium Unemployment as a Worker Discipline Device," Shapiro and Stiglitz (1984) present an agency model which assumes incomplete information about the employee's true effort provision. The model further allows employees to shirk. The core result of their model is the non-shirking condition (NSC), which implies 
that employers should pay wages exceeding the market wage. If shirking is detected by the employer, the employee would lose this wage premium. Therefore, a wage premium on top of the market wage reduces the employee's incentives to shirk. The model requires a positive probability of detection in the case of shirking and a punishment for detected employees. The probability of detection is often referred to as the monitoring intensity of the employer. However, to define the punishment, the market wage has to be distinguished from the wage premium, which is not replaced on the market.

\subsection{Occupational pensions as a wage premium}

As discussed in section 2, occupational pensions are associated with an average monthly contribution of about $€ 100$, which is paid on top of the monthly wage. This additional wage component has a present value and is therefore interpreted as a wage premium. However, the theory also requires that this premium is at risk if an employee shirks. The non-forfeiture clause for employer provided pension suggests a clear distinction between vested pension claims and employees facing the risk of forfeiture, within the first five years of contributions. Within this five-year period, individuals face a severe punishment in the case of job loss, and therefore the employer provided pension reduces incentives for shirking. However, if the pension claims are vested, employees retain their claims. For this latter group, the theory is uncertain about a direct effect of pensions on work effort.

\subsection{Lazear's theory of delayed compensation}

Lazear's theory of delayed compensation advises a compensation scheme which jointly improves the interests of employers and employees (Lazear 1979). He suggests a payment scheme which pays the employee less than the value of marginal product when young and more than the value of marginal product when old. This is optimal for both parties since it increases lifetime income as well as lifetime productivity. The back-loading of contracts lowers incentives for shirking because it induces a punishment in the case of detection, i.e., the employee would lose the higher future earnings prospects.

Even though Lazear (1979) used this theoretical framework to argue for a mandatory retirement date, ${ }^{4}$ he also mentions pensions as an instrument to compensate workers with delay. The theory predicts that pensions as an instrument for delayed compensations lower incentives for shirking and hence should increase the average effort. However, it requires that the delayed compensation would be lost in case shirking is detected. This again is the case as long as the employer provided pension is not vested, i.e., within the first five years of contributions.

\subsection{Previous empirical tests}

Previous empirical tests of these theories mostly exploit the relationship between wage premiums (or pensions) and monitoring, concluding that a negative correlation "confirms" or "proves" the theory (se among others Hutchens (1987)).

Little evidence has been presented on direct effort-enhancing effects of pensions. On the individual level, Luchak and Gellatly (2001) find a positive effect of occupational pensions on continuance commitment but a negative effect on affective commitment. The study neither presents a conclusive result nor the theoretical mechanism of the analyzed relationship. However, evidence using firm-level performance is not conclusive either. While Allen and Clark (1987) find an effect on productivity but no effect on firm 
performance, Schnabel and Wagner (2001) find the opposite, i.e., a positive effect on firm performance but no effect on labor productivity.

In contrast to approaches used in the literature, I use the Utrecht Work Engagement Scale and provide direct evidence on the relationship between occupational pensions and work engagement.

\section{Data}

\subsection{The linked personnel panel}

The primary data source of this article is the German Linked Personnel Panel (LPP). The LPP is a new linked employer-employee data set, in which the establishment-level and the individual-level information is collected from surveys. The surveys of the LPP are jointly developed by the Center for European Economic Research (ZEW), the University of Cologne, and the Institute for Employment Research (IAB). The establishment-level interviews are conducted in face-to-face interviews, ${ }^{5}$ and employees are surveyed in computer assisted telephone interviews. ${ }^{6}$ A unique establishment identifier allows a perfect link between establishments and employees. Together this procedure results in a linked employer-employee data set, which is rich in employment specific information. ${ }^{7}$

On the employee side, the LPP comprises independent individual interviews on a random sample of employees employed at an establishment participating in the employer survey. The employee survey, which includes most of the variables for my analysis, comprises of employment and individual specific characteristics. Most important among the employee specific information is whether the respective person has claims to an employer provided occupational pension. The information about occupational pensions also includes the year in which these occupational pension savings started. From this variable, I construct a variable indicating the risk of forfeiture if pension savings stared within the last five years.

Individual specific characteristics, which I use as control variables, include demographic characteristics such as education (4 categories), age (4 categories), and dummies for gender, family status, and migration background. Further, the individual controls include job specific information on blue/white collar status, temporary contracts, as well as subjective assessments about the perceived job security (3 categories) and the individual conditions of work. Particularly important for the analysis is information about gross wages and bonus payments since I am interpreting the employer provided occupational pension as a premium on top of the regular remuneration.

Furthermore, a unique individual identifier allows a link with administrative individual data from the IAB Employment Histories, which I use to obtain administrative information on occupations (30 categories), job tenure (year dummies) and labor market experience. The procedure proposed by Eberle et al. (2013) allows extracting experience and tenure from the administrative spell data. ${ }^{8}$

\subsection{Analysis sample}

The 2012 cross section is the first wave of the LPP and the data source for the present study. ${ }^{9}$ The full sample includes 860 establishment observations and 7,347 individual observations ${ }^{10}$ employed at one of these workplaces. Of the individuals, $82 \%$ agreed to link the data. Further, I lose some of the observations because of missing values in the covariates, which finally results in a linked data set comprising 785 establishment-level 
observations and 5,024 employee observations (Table 1). Of the individuals, 2,629 have claims from an occupational pension. Of these, 802 employees, representing $15.8 \%$ of the sample, face the risk of forfeiture in the case of a job termination.

\subsection{Work engagement}

In the regression analysis, I investigate whether occupational pensions affect the employees' work engagement. Work engagement is measured by the Utrecht Work Engagament Scale (UWES). The UWES captures three dimensions of individual engagement: vigor, dedication, and absorption (Schaufeli et al. 2006). Vigor is the individual's willingness to invest effort (even in the face of difficulties). A dedicated employee is strongly involved in his work, i.e., experiences a sense of significance, enthusiasm, inspiration, and pride. Absorption captures the employee's level of work concentration. High absorption is observed if time passes by quickly and if the employee has difficulties with detaching himself from work. The UWES comprises responses to nine different statements together capturing these three dimensions of work engagement. I construct the engagement variable as the average over these nine responses for each individual. ${ }^{11}$ Finally, the variable is mean-standardized, which allows an interpretation of the estimated effects in standard deviations of work engagement.

\section{Pension claims across employers}

In this section, I descriptively analyze whether establishment characteristics explain the presence of occupational pension claims. The analysis has a rather descriptive nature but provides important insights. It indicates whether pensions are selective across establishments and points to whether establishment heterogeneity should be considered when analyzing the primary research question: Do occupational pensions combined with a risk of forfeiture affect work engagement?

Previous studies mostly analyze access to pension plans and try to identify firm characteristics, which explain the employers' provision of pensions. For Germany, these studies find that profitability and turnover rates (Schnabel and Wagner 2001), as well as firm size (Dummann 2008) are associated with offering an occupational pension.

Table 1 Linked analysis sample

\begin{tabular}{|c|c|c|c|c|}
\hline & \multirow[t]{3}{*}{ Establishments } & \multicolumn{3}{|c|}{ Employees } \\
\hline & & \multirow[t]{2}{*}{ No pension claims } & \multicolumn{2}{|c|}{ Occupational pension claims } \\
\hline & & & Vested pension claims & Risk of forfeiture \\
\hline \multicolumn{5}{|c|}{ Total LPP sample: } \\
\hline N & 860 & 3,536 & 2,683 & 1,128 \\
\hline in \% & & $48,1 \%$ & $36.5 \%$ & $15.4 \%$ \\
\hline \multicolumn{5}{|c|}{ Linked analysis sample: } \\
\hline \multicolumn{5}{|c|}{ (Employees without missing information who agreed to link their data) } \\
\hline N & 785 & 2,395 & 1,827 & 802 \\
\hline in \% & & $47,7 \%$ & $36.4 \%$ & $16.0 \%$ \\
\hline
\end{tabular}

Data source: LPP 2012 and IAB-Establishment Panel 2012, analysis sample. 
Furthermore, Dummann (2008) shows that firms in Western Germany, as well as firms in manufacturing and the financial sector, are more likely to provide pensions.

I try to replicate those findings in descriptive regressions of pension claims on employer characteristics. The binary dependent variable indicates whether an employee has claims to an employer provided pension:

$$
\text { pension }_{i}=z_{j}^{\prime} * \beta+u_{i}
$$

$\beta$ captures the coefficients of interest explaining which establishments provide pensions. Establishment-level explanatory variables included in $z$ are retrieved from the IAB-Establishment Panel and include information about establishment size (4 categories), profitability, the employer's administrative laziness (calculated as the share of missings in voluntary characteristics of the administrative employment reports), as well as information on worker co-determination, i.e., the establishment's participation in collective bargaining and the existence of a works council. Since I regress an individual-level variable on establishment characteristics, I allow for an establishment-level error correlation in $u$. This also adjusts statistical inference to the true number of establishment-level observations in the data. ${ }^{12}$

$$
\text { pension }_{i}=z_{j}^{\prime} * \beta+x_{i}^{\prime} * \delta+u_{i}
$$

In an alternative specification presented by equation 2, I add individual control variables to control for differences across respondents. The individual control variables in vector $x$ include job specific characteristics and individual characteristics such as those described in section 4.

The results presented in Table 2 are partial effects from an OLS specification. The first column presents the impact of establishment-level characteristics without controlling for individual differences, whereas Column 2 presents partial effects controlling for individual differences. The effects show that worker co-determination is important for occupational pensions. Both works councils and participation in collective bargaining have positive partial effects on pension claims. However, the coefficient indicating collective bargaining falls short of significance in the second specification. Together, this finding is in line with Mitchell (1988), who shows that unionized workers are better informed about pension offers. A positive effect of works councils is also intuitive since works councils have to agree to changes in the pension plan provided by the employer (BetrVG 2001).

In line with Lamla and Coppola (2013), I also include a variable capturing the employer's administrative laziness, which is measured by the share of missing information in voluntary administrative employment reports. ${ }^{13}$ The share of missing information in the administrative reports is assumed to proxy the general administrative laziness. This administrative laziness might be correlated with the provision of pensions, which is also administratively demanding to employers. The results in Table 2 are in line with Lamla and Coppola (2013) and show meaningful negative coefficients for this variable.

Table 2 finally shows a positive relation between pensions and establishment size. Scale economies in pension plan provision can explain this positive relationship (Mitchell and Andrews 1981). Overall, the results show that occupational pensions are selectively distributed across workplaces, and, hence, establishment heterogeneity should be addressed when analyzing the effects of pensions on work engagement. 
Table 2 Establishment characteristics explaining the incidence of pension claims

\begin{tabular}{|c|c|c|}
\hline \multicolumn{3}{|c|}{ Dep. var.: occupational pension claims } \\
\hline & $(1)$ & $(2)$ \\
\hline \multirow[t]{2}{*}{ Works council } & $0.079^{* *}$ & $0.061^{*}$ \\
\hline & $(0.035)$ & $(0.032)$ \\
\hline \multirow[t]{2}{*}{ Collective bargaining } & $0.053^{*}$ & 0.039 \\
\hline & $(0.029)$ & $(0.025)$ \\
\hline \multirow[t]{2}{*}{ Administrative laziness } & $-0.204^{* * *}$ & $-0.148^{* * *}$ \\
\hline & $(0.046)$ & $(0.044)$ \\
\hline \multirow[t]{2}{*}{ East } & $-0.097^{* * *}$ & $-0.050^{*}$ \\
\hline & $(0.026)$ & $(0.028)$ \\
\hline \multicolumn{3}{|l|}{ Firm size } \\
\hline 50-99 employees & & \\
\hline \multirow[t]{2}{*}{ 100-249 employees } & 0.034 & 0.008 \\
\hline & $(0.032)$ & $(0.029)$ \\
\hline \multirow[t]{2}{*}{ 250-499 employees } & $0.070^{* *}$ & 0.041 \\
\hline & $(0.036)$ & $(0.032)$ \\
\hline \multirow[t]{2}{*}{ more than 500 employees } & $0.103^{* * *}$ & $0.073^{* *}$ \\
\hline & $(0.036)$ & $(0.033)$ \\
\hline \multicolumn{3}{|l|}{ Covariates: } \\
\hline Individual controls & no & yes \\
\hline Establishment controls & yes & yes \\
\hline Establishments & 785 & 785 \\
\hline Employees & 5,024 & 5,024 \\
\hline \multicolumn{3}{|c|}{$\begin{array}{l}\text { Cluster robust standard errors in parentheses (cluster=establishment). Asterisks indicate significance levels: *** } \mathrm{p}<0.01,{ }^{*} \\
\mathrm{p}<0.05,{ }^{*} \mathrm{p}<0.1 \text {. The presented estimates are partial effects from weighted linear regressions. Dep. var: indicator that the } \\
\text { employee obtains claims for an occupational pension. Individual controls: occupation ( } 30 \text { categories), perceived job security } \\
\text { ( } 3 \text { categories), indiv. conditions of work, logarithmic gross wage, bonus payments, a white collar indicator, temporary } \\
\text { contracts, tenure (year-dummies), work experience, migration status, gender, age ( } 4 \text { categories), and education ( } 4 \\
\text { categories). Establishment controls: industries ( } 38 \text { categories), profitability ( } 4 \text { categories) and legal form ( } 6 \text { categories). } \\
\text { Data source: LPP } 2012 \text { and IAB-Establishment Panel } 2012 \text {, analysis sample. }\end{array}$} \\
\hline
\end{tabular}

\section{The effects of occupational pensions on engagement}

\subsection{Baseline regression}

In this section, I analyze whether pensions have a positive efficiency wage effect and enhance work engagement. Mean-standardized engagement is the dependent variable in a regression on a dummy variable indicating that the individual obtains claims to an occupational pension.

$$
\text { engagement }_{i}=\text { pension }_{i} * \gamma_{1}+x_{i}^{\prime} * \gamma_{2}+\epsilon_{i}
$$

$\gamma_{1}$ is the treatment effect measuring the effect of occupational pensions. The vector $x$ comprises a large set of employee-specific controls as described in the data section. Most important among these controls is the information about wages and bonus payments, as pensions are interpreted as a premium on top of monthly remuneration.

In order to test the the prediction that a positive effect of pensions is due to the risk of forfeiture, I include the interaction variable risk of forfeiture to the empirical specification (equation 4). The risk of forfeiture indicates a subset of pension claims and is hypothesized to capture most of the effort enhancing effect of pensions.

$$
\text { engagement }_{i}=\text { pension }_{i} * \gamma_{1}+\text { risk offorfeiture }_{i} * \gamma_{2}+x_{i}^{\prime} * \gamma_{3}+\epsilon_{i}
$$


To strengthen results of the risk of forfeiture, $x$ includes flexible controls for the individual's job tenure using year dummies. For the risk of forfeiture, detailed controls for tenure are of particular importance since tenure is likely to be correlated with the risk of forfeiture, which is directly defined by the duration of occupational pensions savings-a variable also indirectly pending on the duration working for the present employer.

The first two columns of Table 3 present the baseline regression results using the specifications of equations 3 and 4 . Conditional on all individual controls, the presented effects capture the partial effect of an occupational pensions and the risk of forfeiture on the mean-standardized work engagement. In column 1 , the effect of a pension is positive but small in size. Turning to the second column, the effect is entirely driven by the subset of individuals facing the risk of forfeiture of their pension claims. For this group of employees, work engagement increases by 0.15 of a standard deviation. Moreover, there appears to be no own effect of pensions without the risk of forfeiture.

\subsection{Results controlling for establishment heterogeneity}

I continue the analysis by addressing establishment heterogeneity, which might be relevant for the results since pensions are selectivity distributed across establishments (see section 5). If pensions are selective in the sense that engaged individuals tend work at establishments in which pensions are prevalent, this could explain the positive effects.

To capture establishment heterogeneity in the regression analysis, I first include establishment-level characteristics as control variables:

$$
\text { engagement }_{i}=\text { pension }_{i} * \gamma_{1}+\text { risk of forfeiture }_{i} * \gamma_{2}+x_{i}^{\prime} * \gamma_{3}+z_{j}^{\prime} * \gamma_{4}+\epsilon_{i}
$$

Vector $z$, which is added in equation 5 , includes observable establishment characteristics. The variables include the establishment size (4 categories), as well as indicator variables for works councils, participation in collective bargaining agreements, and East Germany. Furthermore, $z$ includes the share of missings in voluntary administrative employment reports (defined as administrative laziness, see above), and categorial controls for firm profitability and industries.

Table 3 The mean-standardized effect on work engagement

\begin{tabular}{|c|c|c|c|c|c|c|}
\hline \multirow[t]{2}{*}{ Dependent variable } & \multicolumn{6}{|c|}{ Engagement } \\
\hline & (1) & (2) & (3) & (4) & (5) & (6) \\
\hline \multirow[t]{2}{*}{ Pension } & $0.057^{*}$ & -0.002 & $0.063^{* *}$ & 0.009 & 0.051 & -0.002 \\
\hline & $(0.029)$ & $(0.032)$ & $(0.029)$ & $(0.033)$ & $(0.036)$ & $(0.039)$ \\
\hline Risk of & & $0.155^{* * *}$ & & $0.146^{* * *}$ & & $0.144^{* * *}$ \\
\hline forfeiture & & $(0.041)$ & & $(0.041)$ & & $(0.049)$ \\
\hline Establ. controls & no & no & yes & yes & no & no \\
\hline Establ. fixed effects & no & no & no & no & yes & yes \\
\hline Establishments & \multicolumn{6}{|c|}{785} \\
\hline Employees & \multicolumn{6}{|c|}{5,024} \\
\hline
\end{tabular}

Presented coefficients are partial effects from linear regressions. Clustered standard errors are presented in parentheses (cluster=establishment). Asterisks indicate significance levels: ${ }^{* *} p<0.01,{ }^{* *} p<0.05,{ }^{*} p<0.1$. Dependent variable is the mean-standardized work engagement, i.e. $y_{i}^{*}=\left(y_{i}-\bar{y}\right) / s d(y)$. Individual controls: occupation (30 categories), perceived job security (3 categories), indiv. conditions of work, logarithmic gross wage, bonus payments, a white collar indicator, temporary contracts, tenure (year-dummies), work experience, migration status, gender, age (4 categories), and education (4 categories). Establishment controls: establishment size (4 categories), industries (38 categories), profitability (4 categories) and legal form (6 categories), the establishment's administrative laziness, as well as indicators for works councils, participation in collective bargaining and East Germany.

Data source: LPP 2012 and IAB-Establishment Panel 2012, analysis sample. 
In a second step, I control for an establishment-level fixed effect (in the cross section), which even more flexibly controls for establishment heterogeneity, i.e., for heterogeneity that is unobserved. This provides the full within-establishment transformation, capturing all differences across workplaces:

$$
\text { engagement }_{i}=\text { pension }_{i} * \gamma_{1}+\text { risk of forfeiture }_{i} * \gamma_{2}+x_{i}^{\prime} * \gamma_{3}+\phi_{j}+\epsilon_{i}
$$

The results of occupational pensions and the risk of forfeiture on work engagement controlling for establishment heterogeneity are presented in Columns 3 to 6 of Table 3 . Controlling for observable establishment characteristics (Columns 3 and 4), the effect on engagement is still entirely driven by individuals facing the risk of forfeiture of pension savings. It increases work engagement by 0.15 standard deviations. A similar effect size is obtained in column 6, when including establishment-level fixed effects. After controlling for potential selection across establishments, the risk of forfeiture still has a large effect on work engagement. Suggesting that under the risk of forfeiture, pensions have an efficiency wage effect on engagement.

\section{Robustness checks}

In this section, I examine the robustness of the baseline regression results by controlling for a large variety of personality traits and the perceived work environment. Both the personality of individuals and the work environment may have meaningful impacts on the outcome variable and may also be associated with participation in occupational pension savings. Therefore, including these variables provides a nice test of whether omitted variables influence the results.

\subsection{Personality traits}

In a first step, I add personality traits as additional controls. Many recent studies emphasize the importance of personality traits for treatment assignment (Caliendo and Kritikos 2014). The data allow controlling for the big five personality traits and a self reported measure for risk aversion. The big five might influence the results if they explain the selection in occupational pension plans. For instance, if risk averse employees more likely save in a pension plan to avoid uncertainties about future incomes, this would be an important covariate explaining selection into treatment.

The results presented in Table 4 use the full specification including the interaction with the risk of forfeiture and establishment-level fixed effects (equation 6). Most of the big five personality traits seem to affect work engagement, but they do not affect the results concerning pensions. In fact, the effect remains of similar size, which suggests that the personality variables are not correlated with the incidence of pensions. This finding also suggests that participation in an employer provided pension is rather a choice of the respective employer than of the employee himself, which reduces the likelihood of self-selection.

\subsection{Work environment}

In the second robustness check, I add controls for the individual's perceived work environment. The perception of the working environment is presumably highly relevant for the individual's work engagement and may capture the atmosphere at the workplace. 
Table 4 Regression analysis controlling for personality

\begin{tabular}{|c|c|c|c|}
\hline \multirow[t]{2}{*}{ Dependent variable } & \multicolumn{3}{|c|}{ Engagement } \\
\hline & (1) & (2) & (3) \\
\hline \multirow[t]{2}{*}{ Pension } & 0.002 & -0.008 & -0.001 \\
\hline & $(0.036)$ & $(0.039)$ & $(0.036)$ \\
\hline \multirow[t]{2}{*}{ Risk of forfeiture } & $0.145^{* * *}$ & $0.149^{* * *}$ & $0.147^{* * *}$ \\
\hline & $(0.046)$ & $(0.049)$ & $(0.046)$ \\
\hline \multirow[t]{2}{*}{ Extraversion } & $0.075^{* * *}$ & & $0.069^{* * *}$ \\
\hline & $(0.023)$ & & $(0.023)$ \\
\hline \multirow[t]{2}{*}{ Conscientiousness } & $0.342^{* * *}$ & & $0.344^{* * *}$ \\
\hline & $(0.037)$ & & $(0.037)$ \\
\hline \multirow[t]{2}{*}{ Neuroticism } & $-0.081^{* * *}$ & & $-0.076^{* * *}$ \\
\hline & $(0.023)$ & & $(0.023)$ \\
\hline \multirow[t]{2}{*}{ Openness } & $0.191^{* * *}$ & & $0.180^{* * *}$ \\
\hline & $(0.026)$ & & $(0.026)$ \\
\hline \multirow[t]{2}{*}{ Agreeableness } & $0.129^{* * *}$ & & $0.133^{* * *}$ \\
\hline & $(0.028)$ & & $(0.028)$ \\
\hline \multirow[t]{2}{*}{ Risk-taking } & & $0.045^{* * *}$ & $0.020^{* *}$ \\
\hline & & $(0.009)$ & $(0.009)$ \\
\hline Establishments & & 785 & \\
\hline Employees & & 5,024 & \\
\hline
\end{tabular}

Cluster robust standard errors in parentheses (cluster=establishment). Asterisks indicate significance levels: ${ }^{* * *} \mathrm{p}<0.01$, ${ }^{* *} p<0.05,{ }^{*} p<0.1$. All specifications as specified in equation 6 . For further notes, see Table 3 .

Therefore, this second robustness check also evaluates whether the estimated effect is co-determined by some other unobserved underlying effect at the workplace.

The data allow controlling for four different variables associated with the work environment:

1. Clarity of goals describes how clear and present the goals of the employer are perceived by the employee.

2. Supervisory support: The variable indicates how supportive an trustworthy an employee evaluates the relationship to his supervisor.

3. Cooperativeness captures how cooperative an employee assesses the work environment.

4. Fairness depicts the perceived fairness of rules and their execution at the respective workplace.

Table 5 presents the partial effects of pensions, the risk of forfeiture, and the work environment's own effect on engagement using the specification of equation 6 . The results show that each of the subjective variables describing the work environment has a large and significant impact on engagement. Some of these variables slightly reduce the effect of the risk of forfeiture on engagement, but it remains statistically significant and economically relevant in size. Concluding for this second robustness check, the efficiency wage effect of pensions is robust against controls capturing the self-assessed work environment; therefore, it is unlikely that the estimates capture an effect of some other effect correlated with the work environment. 
Table 5 Regression analysis controlling for the work environment

\begin{tabular}{|c|c|c|c|c|c|}
\hline \multirow[t]{2}{*}{ Dependent variable } & \multicolumn{5}{|c|}{ Engagement } \\
\hline & (1) & (2) & (3) & (4) & (5) \\
\hline \multirow[t]{2}{*}{ Pension } & -0.002 & 0.009 & -0.009 & -0.009 & -0.002 \\
\hline & $(0.038)$ & $(0.036)$ & $(0.038)$ & $(0.038)$ & $(0.036)$ \\
\hline \multirow[t]{2}{*}{ Risk of forfeiture } & $0.138^{* * *}$ & $0.134^{* * *}$ & $0.148^{* * *}$ & $0.129^{* * *}$ & $0.130^{* * *}$ \\
\hline & $(0.048)$ & $(0.046)$ & $(0.049)$ & $(0.046)$ & $(0.046)$ \\
\hline \multirow[t]{2}{*}{ Clarity of goals } & $0.238^{* * *}$ & & & & $0.090^{* * *}$ \\
\hline & $(0.019)$ & & & & $(0.020)$ \\
\hline \multirow[t]{2}{*}{ Superv. Support } & & $0.375^{* * *}$ & & & $0.216^{* * *}$ \\
\hline & & $(0.021)$ & & & $(0.024)$ \\
\hline \multirow[t]{2}{*}{ Helping } & & & $0.317^{* * *}$ & & $0.143^{* * *}$ \\
\hline & & & $(0.030)$ & & $(0.030)$ \\
\hline \multirow[t]{2}{*}{ Fairness } & & & & $-0.368^{* * *}$ & $-0.181^{* * *}$ \\
\hline & & & & $(0.022)$ & $(0.025)$ \\
\hline Establishments & & & 785 & & \\
\hline Employees & & & 5,024 & & \\
\hline
\end{tabular}

Cluster robust standard errors in parentheses (cluster=establishment). Asterisks indicate significance levels: *** $p<0.01$, ${ }^{*} \mathrm{p} p<0.05,{ }^{*} p<0.1$. All specifications as specified in equation 6 . For further notes, see Table 3 .

\section{Pensions and the distribution of engagement}

So far, the estimates show that the risk of forfeiture has a positive impact on the average level of work engagement. However, the theories of Shapiro and Stiglitz (1984) and Lazear (1979) imply that pensions can reduce incentives for shirking. I assume that shirking is represented by particularly low levels of work engagement and, hence, expect a large effect at the lower end of the engagement distribution. To assess the effect size across the engagement distribution, I conduct conditional quantile regressions.

To provide a brief description of the the mean-standardized density of engagement, I first present a kernel density in panel A of Figure 2. Conditional quantile effects from the specification without establishment heterogeneity, as specified in equation 4 , are presented in panel B of Figure 2. The diamonds in panel B present point estimates of the variable indicating pension coverage and the risk of forfeiture, as well as the respective 95\%-confidence intervals for both variables' coefficients.

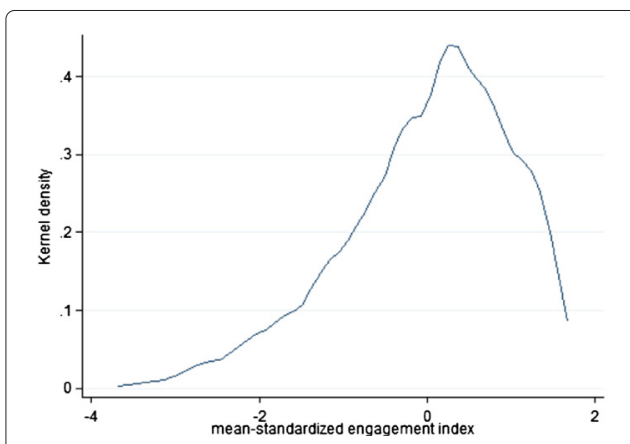

a) Distribution of engagement

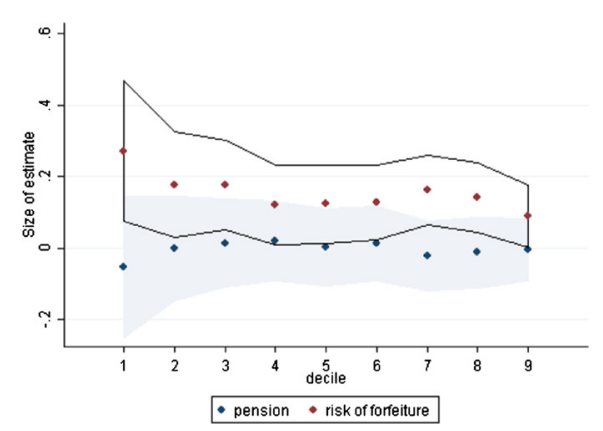

b) Quantile regression estimates

Figure 2 The distribution of work engagement and the effect on work engagement. (a) Distribution of engagement. (b) Quantile regression estimates. Note: Conditional quantile regression estimates as specified in equation 4. Estimates are presented in Additional file 2: Online Appendix A. 
The presented effect pattern across the distribution of engagement indicates that the effect of the risk of forfeiture is mostly driven by an increase of the conditional distribution at the lowest deciles. However, from a statistical perspective, the estimates are not different across deciles. Nevertheless, the observed pattern matches with the theoretical prediction expecting a reduced incentive for shirking, i.e., a large positive effect in the lower tail of the conditional distribution.

\section{Conclusion}

I analyze whether employer provided occupational pensions have an efficiency wage effect by enhancing the employees' work engagement. Efficiency wage theories suggest that pensions affect work effort, but only in the presence of a credible threat that pension claims are lost as shirking is detected. I exploit the non-forfeiture clause, which determines the conditions to which pension claims are lost in the case of a job termination. Within the first five years of contributions to an occupational pension, employees face the risk of forfeiture, but after this period, pension claims are vested. The theory predicts reduced incentives for shirking if employees face the risk of forfeiture.

Applying this theoretical prediction to the LPP, I find a significant and positive effect of occupational pensions on work engagement when the risk of forfeiture is present. The risk of forfeiture increases work engagement by 0.15 of a standard deviation. However, the results do not show a direct effect of pensions on engagement, i.e., when pensions claims are vested.

In the first part of the analysis, I present descriptive regressions indicating that occupational pension claims are distributed selectively across establishments. However, when I control for workplace heterogeneity in the regression of work engagement on pensions and the risk of forfeiture, the point estimates remain unchanged. Further robustness checks, which control for the employee's personality and the perceived work environment, all show similar effect sizes and confirm the efficiency wage effect of pensions in the presence of the risk of forfeiture.

Finally, conditional quantile regressions indicate that the lower deciles are particularly affected by the risk of forfeiture. This finding is in line with the efficiency wage theories, which predict a reduced incentive for shirking.

If work engagement is a good proxy for productivity, this efficiency wage effect is socially desirable and a valid argument in favor of vesting times for employer provided pensions. This adds an argument to the discussion about vesting times. Previous studies found a negative relationship between pensions and turnover rates because of the risk of forfeiture (Rabe 2007). This negative effect on turnover might be desirable for employers, but it also indicates labor market rigidity, which should rather be abolished. However, the positive effect on work engagement should be in favor of employers and employees and, therefore, provides a clear argument to preserve the regulation on vesting times.

Moreover, the risk of forfeiture solves the puzzle which I raised in the motivation of this article: a rational employer provides pensions only if he receives something in return for the costly contributions. A higher level of work engagement could potentially constitute the gift in exchange for the employer's contributions. However, this effect requires vesting times for occupational pensions, which still exist, but have been deregulated in previous decades. 


\section{Endnotes}

${ }^{1}$ Even though the private sector is not covered in the data, the same regulation holds true. Employees only retain their pensions after expiry of the non-forfeiture clause.

${ }^{2}$ The "Entgeltumwandlungsanspruch," which came into force in 2002, gave employees the right to save part of their gross salary in an occupational pension plan. On demand of an employee, employers are obligated to withhold a share of the gross wage in an occupational pension plan. The deduction is made before tax such that employees save a share of income tax, and both employers and employees save a share of the social security contribution.

${ }^{3}$ Individuals usually receive a yearly transcript of their savings including a prediction of monthly pensions after retirement.

${ }^{4}$ Individuals have an incentive to delay their retirement if they are paid more than their marginal product. Hence, politics should set a timing for mandatory retirement.

${ }^{5}$ The establishment interviews are conducted by TNS Infratest Sozialforschung, which is the largest German institute for social science and political science research data collection. The survey is conducted jointly with the IAB-Establishment Panel, which is the largest and most comprehensive annual establishment survey in Germany. This link ensures high data quality. Establishments are drawn as a sub-sample of large plants participating in the IAB-Establishment Panel with at least 50 employees. The LPP includes probability weights, which allow adjusting for non-random sampling, making the results representative for private sector establishments in Germany with at least 50 employees. All estimations are replicated using sampling weights and are presented in Additional file 2: Online Appendix B.

${ }^{6}$ The employee survey is conducted by the Institute for Applied Social Sciences (infas).

${ }^{7}$ A comprehensive description of the LPP is provided by Bellmann et al. (2015).

${ }^{8}$ I also use administrative information on daily gross wages to impute missing wage information in the survey responses. This ensures that results are not driven by survey non-response in the wage variable. I observe survey non-response in wages for about $10 \%$ of the observations.

${ }^{9}$ Establishments were interviewed between July and September 2012, and employees were independently interviewed between November 2012 and February 2013.

${ }^{10}$ This comprises all employee observations with valid information on occupational pensions.

${ }^{11}$ The presented results are fully robust to an alternative summation of the nine work engagement items using a principle component factor analysis. The estimation results for this alternative outcome variable are presented in Additional file 2: Online Appendix C.

${ }^{12}$ Since individual observations are used in a regression with establishment information, establishment clusters adjust for the sample size in the calculation of standard errors.

${ }^{13}$ The variable is obtained from the administrative employment histories and captures the share of employees for which no qualification is reported. Employers are asked but not required to report a level of qualification for each employee. None of the results in this paper pend on the inclusion of this variable.

\section{Additional files}

Additional file 1: Supplementary table.

Additional file 2: Online appendices. Online Appendix A — Quantile regression results. In this online appendix, I present the numerical regression results included in figure 2. Online Appendix B - Weighted regression results. In this online appendix, I replicate regressions using survey's sampling weights. Online Appendix C - Alternative engagement index. In this online appendix, I replicate regressions using an alternative dependent variable retrieved from a factor analysis. 


\section{Competing interests}

The IZA Journal of European Labor Studies is committed to the IZA Guiding Principles of Research Integrity. The author declares that he has observed these principles.

\section{Acknowledgements}

For helpful comments and fruitful discussions, I thank Lutz Bellmann, Martin Murmann, Oivind Anti Nilsen, and Richard Upward. I also thank seminar participants at the IAB and the University of Erlangen-Nuremberg, as well as the conference participants of the workshop "New firms and the quality of work" in Tübingen, the 2014 Colloquium on Personnel Economics in Cologne and the LASER-conference "Labor market prospects of older workers" in Nuremberg for helpful comments and suggestions. The author visited University of Nottingham during the work on this project and is thankful for their hospitality. The author would like to thank the anonymous referee.

Responsible editor: Alan Barrett

\section{Received: 16 October 2014 Accepted: 12 February 2015}

Published online: 24 April 2015

\section{References}

Akerlof GA (1982) Labor contracts as partial gift exchange. Q J Econ 97(4):543-569

Allen SG, Clark RL (1987) Pensions and Firm Performance. In: Kleiner MM, Block RN, Roomsted M, Salsburg SW (eds). Human Resources and the Performance of the Firm. Industrial Relations Research Association, Madison, Wisc. pp 159-242

Andrietti V (2001) Occupational Pensions and Interfirm Job Mobility in The European Union. Evidence from The ECHP Survey. Madrid and Turin: Universidad Carlos III de Madrid, Department of Economics and Center for Research on Pensions and welfare policies, University of Turin

Bauer TK, Bender S, Bonin H (2007) Dismissal protection and worker flows in small establishments. Economica 74(296):804-821

Bellmann L, Gerner H-D, Upward R (2011) Job and worker turnover in German establishments, IZA discussion paper 6081. Bonn: IZA

Bellmann, L, Gerner H-D, Upward R (2013) Employment adjustment in German firms: more flexible than we thought? (in German). J Labour Mark Res 47(1-2):71-81

Bellmann L, Bender S, Bossler M, Broszeit S, Dickmann C, Gensicke M, Gilberg R, Grunau P, Kampkötter P, Laske K, Mohrenweiser J, Schröder H, Schütz H, Sliwka D, Steffes S, Stephani J, Tschersich N, Wolter S (2015) LPP - Linked Personnel Panel * quality of work and economic success: Iongitudinal study in German establishments (data collection on the first wave), FDZ-Methodenreport, 05/2015 (en). Nuremberg: IAB-Forschungsdatenzentrum

BetrVG (ed.) (2001) Betriebsverfassungsgesetz, Article 87 (1) Nr. 8. http://www.gesetze-im-internet.de/betrvg/

BetrAVG (ed.) (2009) Betriebsrentengesetz, Article 1b (1): Unverfallbarkeit und Durchführung der Betrieblichen Altersversorgung. http://www.gesetze-im-internet.de/bundesrecht/betravg/

Bundesarbeitsgericht (1972) Rechtsprechung des BAG, Az:: 3 AZR 278/71. https://www.jurion.de/Urteile/BAG/1972-0310/3-AZR-278_71

Caliendo FFM, Kritikos AS (2014) Personality Characteristics and The Decision to Become and Stay Self-Employed. Small Bus Econ 42(4):787-814

Dummann K (2008) What determines supply and demand for occupational pensions in Germany? . J Pension Econ Finance $7(2): 131-156$

Eberle J, Schmucker A, Seth S (2013) Example programs for data preparation of the sample of integrated labour market biographies for Stata * creating cross-sectional data and biographical variables, FDZ-Methodenreport, 04/2013 (en). Nuremberg: IAB-Forschungsdatenzentrum

Even WW, Macpherson DA (1996) Employer size and labour turnover: the role of pensions. Ind Labour Relat Rev 49(4):707-728

Fuchs J, Söhnlein D (2013) Projektion der Erwerbsbevölkerung bis zum Jahr 2060, IAB-Forschungsbericht 10/2013. Nuremberg: Institute for Employment Research. IAB-Forschungsbericht 10/2013, Nürnberg

Gustman AL, Steinmeier TL (1993) Pension portability and labor mobility: Evidence from the survey of income and program participation. J Public Econ 50(3):299-323

Gustman AL, Mitchell OS, Steinmeier TL (1994) The Role of Pensions in the Labor Market: A Survey of the Literature. Ind Labor Relat Rev 47(3):417-438

Henley A, Disney R, Carruth A (1994) Job Tenure and Asset Holdings. Econ J 104(423):338-349

Hernaes E, Piggott J, Zhang T, Strom S (2011) Occupational pensions, tenure, and taxes. J Pension Econ Finance 10(03):435-456

Hutchens RM (1987) A Test of Lazear's Theory of Delayed Payment Contracts. J Labor Econ 5(4-2):153-170

Lamla B, Coppola M (2013) Is it All About Access? Perceived access to occupational pensions in Germany, Discussion Paper 277. Munich: Munich Center for the Economics of Aging

Lazear E (1979) Why is there mandatory retirement?. J Pol Econ 87(6):1261-1284

Luchak AA, Gellatly IR (2001) What Kind of Commitment Does a Final-Earnings Pension Plan Elicit? Relat Ind Relat 56(2):394-417

McCormick B, Hughes G (1984) The influence of pensions on job mobility. J Publ Econ 23(1-2):183-206

Mealli F, Pudney S (1996) Occupational pensions and job mobility in Britain: Estimation of a random-effects competing risks model. J Appl Econometrics 11(3):293-320

Mercer (2013) Melbourne Mercer Global Pension Index. Melbourne: Australian Centre for Financial Studies

Mitchell OS (1988) Worker knowledge of pension provisions. J Labor Econ 6(1):21-39

Mitchell OS, Andrews ES (1981) Scale economies in private multi-employer pension systems. Ind Labor Relat Rev 34(4):522-530

Rabe B (2007) Occupational Pensions, Wages, And Job Mobility In Germany. Scott J Pol Econ 54(4):531-552 
Schaufeli WB, Bakker AB, Salanova M (2006) The measurement of work engagement with a short questionnaire a cross-national study. Educ Psychol Meas 66(4):701-716

Schnabel C, Wagner J (2001) A note on pensions and firm performance: First evidence from german micro data. J Labor Res 22(1):207-211

Shapiro C, Stiglitz JE (1984) Equilibrium unemployment as a worker discipline device. Am Econ Rev 74(3):433-444

Taylor S (2000) Occupational pensions and employee retention: Debate and evidence. Employee Relat 22(3):246-259

TNS Infratest Sozialforschung (2012) Situation und Entwicklung der Betrieblichen Altersversorgung in Privatwirtschaft und öffentlichem Dienst (BAV 2011). Forschungsbericht des Bundesministeriums für Arbeit und Soziales, Munich, Germany The World Bank (1994) Averting the Old Age Crisis. New York: Oxford University Press

Submit your manuscript to a SpringerOpen ${ }^{\circ}$ journal and benefit from:

- Convenient online submission

- Rigorous peer review

- Immediate publication on acceptance

- Open access: articles freely available online

- High visibility within the field

- Retaining the copyright to your article

Submit your next manuscript at $\gg$ springeropen.com 